\title{
GÊNERO CHARGE: CONSTRUÇÃO DE SIGNIFICADOS A PARTIR DE UMA PERSPECTIVA INTERDISCIPLINAR E DINÂMICA
}

\author{
Jorge Bidarra ${ }^{1}$ \\ Leidiani da Silva Reis ${ }^{2}$
}

\section{RESUMO}

O presente trabalho discute e analisa o processo interpretativo do gênero charge, levando em consideração o seu papel no contexto ensino-aprendizagem. Para tanto, a discussão é pautada na abordagem sociointeracionista da linguagem, para a qual o texto deve ser visto como uma atividade interacional, criativa e social. Partindo-se desse ponto de vista, interpretar um texto torna-se uma tarefa complexa, que requer estratégias cognitivas e metacognitivas. Para efeito de sondagem, selecionamos a Charge "Eleição para Papa", de autoria de Alberto Benett (2013). Ao longo do texto, mostraremos que, no caso de charges, um dos requisitos fundamentais é o estabelecimento da intertextualidade, mormente com o envolvimento de outros textos jornalísticos. Observamos ainda que, em tal circunstância, sem o devido acionamento de conhecimentos prévios (conhecimentos de mundo e linguístico, por exemplo), a interpretação realizada pelo leitor tende a falhar. Por se tratar de um gênero composto pela mistura de linguagem verbal com a não verbal (pictórica), a charge tem sido considerada um material muito rico para ser trabalhado com alunos em salas de aulas. A interpretação desse gênero textual requer, muitas vezes, conhecimentos que envolvem não só a política e a religião, mas também fatos históricos, geográficos, artísticos e de linguagem. O caráter humorístico, informativo e opinativo das charges, bem como a ampla circulação social que assumem, fazem da charge um instrumento importante para a formação de alunos críticos e reflexivos, atributos cada vez mais solicitados pela sociedade.

Palavras-chave: Interpretação textual. Texto. Gênero charge. Interdisciplinaridade. Ensino-Aprendizagem.

\section{INTRODUÇÃO}

O mundo se encontra em constante evolução, envolto numa ebulição que perpassa não apenas por questões econômico-financeiras, mas também pelas sociais e religiosas, das quais tomam parte, inclusive, as diferentes formas de comunicação praticada pelos povos. No que diz respeito às linguagens, os gêneros textuais utilizados nos mais diversos ambientes têm-se mostrado revolucionários, especialmente nos últimos tempos. Pesquisas apontam que, no mundo moderno, boa parte das mudanças provocadas nas formas de comunicação tem origem no 
avanço da tecnologia. Com ela, surgem novos gêneros, alguns se adaptam e outros, avançam, (Cf. BAKHTIN, 2003). Nesse processo, uma das manifestações literárias que vêm ganhando espaço na sociedade de uma maneira geral e, em particular, nas escolas, são as charges. Gênero rico em informações, expressas por meio de desenhos e caricaturas, acompanhados ou não por textos escritos, as charges constituem um excelente material pedagógico para ser trabalhado com os alunos. Com suas características interdisciplinares e dinâmicas, as charges se revelam um grande desafio para os alunos, porque, através delas, eles se veem obrigados, dentre outras coisas, a fazerem inferências entre o dito e o não dito no texto. Tal provocação tende a despertar nos alunos o interesse, a curiosidade, a pesquisa, fazendo deles indivíduos críticos e realmente reflexivos.

Por suas muitas facetas, consideramos relevante abrir aqui um espaço para que possamos, juntos, olhar com mais atenção o gênero charge, não apenas pelo seu aspecto, muitas vezes, engraçado., mas antes como um elemento importante para a formação de alunos formadores de opiniões. Iniciamos essa apresentação a partir da concepção de linguagem à luz do sociointeracionismo, principal base teórica adotada em nosso trabalho de pesquisa. Também consideramos nesse estudo o texto como uma atividade social, interativa, dinâmica e criativa. Discutimos, rapidamente, o papel da leitura, tendo em vista o relacionamento existente entre os processos cognitivos acionados pelos leitores no momento da interpretação de uma obra e sua compreensão a respeito do que ela veicula. Na sequência, considerando os pressupostos acima discutidos e tomando por verdade que o ato de interpretar não se reduz a simples decodificação de textos, colocamos em debate o conceito embutido na tarefa de uma interpretação textual mais elaborada. Apresentamos ainda algumas estratégias consideradas pelos estudiosos como sendo as mais relevantes no processo de construção do significado do gênero em questão.

No que segue, para material de estudo e discussão, tomamos como objeto de análise a charge publicada por Alberto Benett (2013), intitulada a "Eleição para Papa". Esta charge nos chamou a atenção justamente pela interessante mistura de ingredientes que o chargista arrolou em sua obra, na qual se apresentam, lado a lado, referências aos muitos arranjos comumente usados nos partidos políticos brasileiros e o fato internacional, não só de cunho religioso, mas também político e social, que tanto caracterizou a recente eleição para o Papa da igreja católica. Apoiados em discussões teóricas, desenvolvemos ao longo do texto algumas 
reflexões acerca da função que a estratégia interpretativa adotada no gênero charge assume na construção de sentidos de um texto. Por fim, são apresentadas as nossas considerações gerais e suas perspectivas para trabalhos futuros.

\section{A LINGUAGEM NUMA PERSPECTIVA SOCIOINTERACIONISTA}

Assumindo que os discursos são elaborados para atingir as pessoas naquilo que seriam as intenções de seus produtores, para entendermos a complexidade de todo esse processo, é necessário que consideremos como um fato que a compreensão da mensagem por parte dos receptores da resulta mobilização tanto dos gêneros quanto dos mecanismos textuais (KOCH e MARCUSCHI, 1998) que melhor possam responder aos objetivos pretendidos. Admitindo-se que a linguagem, de acordo com a teoria interacionista, resulta de um processo de interação intensa, os sujeitos envolvidos no ato assumem papéis de "atores/construtores sociais, sujeitos ativos que - dialogicamente - constroem-se e são construídos no texto, considerado o próprio lugar da interação e da constituição dos interlocutores" (KOCH e ELIAS, 2006, p. 10-11).

Nessa perspectiva, dadas as condições de produção do discurso, Koch (2001, p. 9) diz que

[...] a linguagem é vista como um modo de ação social. É o elemento de mediação necessária entre o homem e a sua realidade, neste sentido, é lugar de conflito, de confronto dialógico em que a significação se apresenta em toda a sua complexidade. Estudar a linguagem é abarcá-la nessa complexidade, é apreender o seu funcionamento que envolve não só mecanismos linguísticos, mas também extralinguísticos.

Mais do que servir de meio para a transmissão de informações de um emissor a um receptor,

[...] usar a língua não é tão somente traduzir e interiorizar um pensamento ou transmitir informações a outrem, mas sim realizar ações, agir, atuar, sobre o interlocutor (ouvinte/falante). A linguagem é, pois, um lugar de interação humana. (TRAVAGLIA, 2000, p. 23).

Sendo assim, parece razoável afirmar que a linguagem se apresenta como uma atividade imanentemente social, uma vez que as palavras e as formas usadas pelo produtor e que, ao final, devem ser compreendidas pelo receptor, constituem vozes sociais e históricas que dão ao pronunciamento, seja ele um texto ou um discurso, determinadas significações concretas (BAKHTIN, 2002). A compreensão 
da linguagem como produto dos processos sociais corresponde, desse modo, ao entendimento de que ela se origina no campo de atuação do homem e é, pois, consequência da sua ação e intervenção sobre a realidade.

\section{A LEITURA E O TEXTO NO CONTEXTO DAS ATIVIDADES SOCIAIS E DISCURSIVAS}

Sendo o "processo de aquisição e uso da linguagem relacionada entre o cognitivo e o social" (MACHADO, 2002, p. 33) e que a língua, em particular, é a ação entre os homens $(\mathrm{KOCH}, 2001)$, a leitura não mais pode ser senão a tomada como um ato social, uma forma de interação movida por precisões e objetivos socialmente definidos; ou seja, "uma atividade interativa altamente complexa de produção de sentidos" (KOCH e ELIAS, 2006, p. 11). Partindo-se dessa visão, a leitura, neste trabalho, é tomada como uma atividade a ser ensinada na escola, não como mero pretexto para outras atividades e outros tipos de aprendizagem (KLEIMAN, 2004), mas como uma "atividade em que resignificamos a palavra, apoiados na nossa experiência prévia, focalizando significados de palavras específicas ou para inferir seu significado, ou para apreciar um uso particular, diferente" (KLEIMAN, 2004, p. 20).

Dito de outro modo, partimos da concepção de que um texto é "toda ocorrência linguística falada ou escrita, de qualquer extensão, dotada de uma unidade sócio comunicativa, semântica e formal” (COSTA VAL, 1999, p. 3). Nesses termos, vamos assumir que se há comunicação e sentido, há texto. Assim, um texto

[...] se constitui enquanto tal no momento em que os parceiros de uma atividade comunicativa global, diante de uma manifestação linguística, pela atuação conjunta de uma complexa rede de fatores de ordem situacional, cognitiva, sociocultural e interacional, são capazes de construir, para ela, determinado sentido. (KOCH, 2008, p. 30).

Diremos, pois, que tudo o que é passível de significado é considerado um texto, algo que vai desde o escrito, passando pela imagem até um objeto. Nessa nossa concepção, quem o produziu, o fez com intenções e objetivos a serem atingidos. E o que acontece com a charge é exatamente isso. Nem sempre ela vem composta da linguagem verbal; porém, cada imagem ali representada tem uma situação significativa, retratando determinado contexto social. Assim, não há um sentido único para o texto; há, sim, leituras, mais ou menos, adequadas, 
dependendo dos objetivos e das intenções do produtor do texto e do leitor (KLEIMAN, 2004).

Como sugerido por Koch (2008), a produção textual é uma atividade, ao mesmo tempo,

i. verbal e não verbal, a serviço de fins sociais e, portanto, inserida em contextos mais complexos de atividades;

ii. consciente e criativa que compreende o desenvolvimento de estratégias concretas de ação e a escolha de meios adequados à realização de objetivos. Trata-se de uma atividade intencional que o falante, em conformidade com as condições sob as quais o texto é produzido, empreende, tentando dar a entender seus propósitos aos destinatários através do meio escolhido para tal e

iii. interacional, uma vez que os interactantes, de maneiras diversas, também se acham envolvidos na atividade de produção textual.

Se, por um lado, devemos olhar para o texto como o resultado de um conjunto de operações realizadas por um sujeito que, numa situação discursiva, busca atingir certos objetivos, por outro, devemos compreendê-lo como produto de ação que se volta para um processo de interação, em que alguns indícios discursivos permitem avaliação das condições de produção e dos diferentes movimentos argumentativos que sustentam determinada conclusão. Como nos chama a atenção Kleiman (2004, p. 23), "tanto o texto oral quanto o texto escrito são produtos de uma intencionalidade, isto é, escritos por alguém, com alguma intenção de chegar aos outros".

Ainda conforme Kleiman (2004), a experiência do leitor é indispensável para construir o sentido do texto. Isso porque ele tem "seus conhecimentos, suas experiências, as quais interagem com o texto, que é marcado por pistas deixadas pelo autor no momento da produção" (STRIQUER, 2007, p. 40).

Maria Helena Martins (2006) também nos brinda com grandes contribuições para esse debate. Para ela, desenvolver a leitura "significa também aprender a ler o mundo, dar sentido a ele e a nós próprios" (MARTINS, 2006, p. 34). Ilustrativamente, de acordo com a autora, tudo o que pode ter um significado é passível de leitura, de um livro, um artigo ou uma charge a um quadro exposto na parede de uma casa. Se a essas formas de expressão são atribuídos significados, temos diante de nós um texto: 
[...] ao falar em leitura, podemos ter em mente alguém lendo jornal, revista, folheto, mas o mais comum é pensarmos em leitura de livros. Mas não bastará apenas decifrar palavras para acontecer a leitura, pois o ato de ler vai além da escrita. Em todo momento você está praticando a leitura. Tudo o que é carregado de significado é passível de leitura. (MARTINS, 2006, p. 21).

De acordo com o exposto até aqui, já podemos dizer com mais segurança que um leitor competente é exatamente aquele que tem essa capacidade de interagir com o texto e com o autor, de atribuir sentido ao que lê considerando o contexto de enunciação envolvido no processo. Para ser bem sucedido na tarefa da leitura, interpretação e compreensão, o leitor, face às várias possibilidades a seu dispor, seleciona aquelas que respondem as suas necessidades, para o quê vai se valer de estratégias adequadas a fim de alcançar os significados implícitos deixados pelo autor/artista.

Deixando um pouco de lado os teóricos, os PCNs (Parâmetros Curriculares Nacionais) afirmam que "formar um leitor competente supõe formar alguém que compreenda o que lê; que possa aprender a ler também o que não está escrito, identificando elementos implícitos; que estabeleça relações entre o texto que lê e outros textos já lidos" (BRASIL, 1998, p. 54).

Mas, para que o aluno possa fazer esse percurso e atingir esse nível de habilidade, o professor deverá auxiliá-lo. Como professores, não podemos nos esquecer de que a formação de um leitor competente passa, necessariamente, pelo ensino de estratégias de leitura, pela prática em textos sociais, pelo desenvolvimento de autonomia do leitor para escolher a estratégia que lhe pareça mais adequada para a interpretação apropriada. Para Rojo (2002), ler é

[...] escapar da literalidade dos textos e interpretá-los, colocando-os em relação com outros textos e discursos, de maneira situada na realidade social; é discutir com os textos, replicando e avaliando posições e ideologias que constituem seus sentidos; é, enfim, trazer o texto para a vida e colocálo em relação com ela. Mais que isso, as práticas de leitura na vida são muito variadas e dependentes de contexto, cada um deles exigindo certas capacidades leitoras e não outras. (ROJO, 2002, p. 1).

\section{O PROCESSO INTERPRETATIVO: DESVELANDO ALGUMAS ESTRATÉGIAS}

Por definição, de acordo com Menegassi (1995, p. 26), "estratégias são procedimentos conscientes ou inconscientes utilizados pelo leitor para decodificar, 
compreender e interpretar o texto". Kleiman (2009), por seu turno, as caracteriza como procedimentos de base cognitiva e metacognitiva. As estratégias cognitivas, em especial, são essenciais no momento da leitura. Elas são as ações mentais inconscientes de que o leitor nem sempre tem consciência:

As estratégias cognitivas regem os comportamentos automáticos, inconscientes do leitor, e o seu conjunto serve essencialmente para construir a coerência local do texto, isto é, aquelas relações coesivas que se estabelecem entre elementos sucessivos, sequenciais no texto. (KLEIMAN, 2009, p. 50. Grifo da autora).

Quanto às estratégias metacognitivas, Kleiman (2009) as refere como as operações sobre as quais o leitor tem domínio no ato da interpretação. Para a autora, essa é "uma estratégia de controle e regulamento do próprio conhecimento" (KLEIMAN, 2009, p. 34).

Kleiman (2009) elenca alguns passos necessários ao ato de interpretar e que vão demandar do leitor/ouvinte, logo de início, conhecimentos prévios adquiridos durante toda a sua vida. São eles que, conforme a autora, "determinam as possíveis inferências realizadas com base em marcas formais do texto" (KLEIMAN, 2009, p. 26). Nesse processo, estariam envolvidos, ainda conforme Kleiman, três níveis de conhecimento que devem estar articulados pelo leitor durante o seu trabalho interpretativo e que seriam:

O conhecimento linguístico, o conhecimento textual, o conhecimento de mundo devem ser ativados durante a leitura para poder chegar ao momento da compreensão, momento esse que passa desapercebido, em que as partes discretas se juntam para fazer um significado. (KLEIMAN, 2009, p. 26).

O conhecimento linguístico a que a autora se refere (KLEIMAN, 2009, p. 13) "abrange desde o conhecimento sobre como pronunciar português, passando pelo conhecimento de vocabulário e regras da língua, chegando até o conhecimento sobre o uso da língua". Via esse conhecimento, o leitor identifica as palavras e percebe as relações estabelecidas entre elas, ativando os significados com base em sua competência e performance linguística (sintático, lexical e semântico), sem cujo suporte a compreensão do texto torna-se inviável.

Quanto ao conhecimento textual, trata-se do "conjunto de noções e conceitos sobre o texto" (KLEIMAN, 2009, p. 26). É esse o conjunto que vai permitir ao falante o reconhecimento dos diversos tipos de textos como pertencentes a cada gênero ou tipo textual. Por exemplo, se o leitor tem alguma proficiência em textos informativos, 
descritivos, argumentativos etc., ele já dispõe de uma estrutura formada a respeito desse tipo de texto, ativando-a sempre que se depara com textos dessa natureza. Quanto maior for seu conhecimento textual e seu contato com diferentes tipos de texto, mais facilmente chegará à compreensão (KLEIMAN, 2009).

O conhecimento de mundo, por sua vez, diz respeito aos conhecimentos já adquiridos e mentalizados ao longo da vida de cada pessoa, abarcando "desde o conhecimento que um cientista tem sobre sua especialidade [...] até o conhecimento de que 'é proibido fumar nos coletivos"' (FÁVERO, 2009, p. 73). Embora não linguísticas, essas informações contribuem fortemente para a leitura e sua compreensão.

O quadro a seguir resume os conceitos apresentados:

Quadro 01 - Conhecimento prévio

\begin{tabular}{|c|c|c|}
\hline \multicolumn{3}{|c|}{ CONHECIMENTO PRÉVIO } \\
\hline $\begin{array}{l}\text { Conhecimento } \\
\text { Linguístico }\end{array}$ & Conhecimento Textual & $\begin{array}{c}\text { Conhecimento de } \\
\text { Mundo }\end{array}$ \\
\hline $\begin{array}{lr}\text { "Abrange } & \text { desde } \\
\text { conhecimento sobre como } \\
\text { pronunciar } & \text { português, } \\
\text { passando } & \text { pelo } \\
\text { conhecimento } & \text { de } \\
\text { vocabulário e regras da } \\
\text { língua, chegando até o } \\
\text { conhecimento sobre o uso } \\
\text { da língua" } \\
\text { (KLEIMAN, }\end{array}$ & $\begin{array}{l}\text { "Conjunto de noções e } \\
\text { conceitos sobre o texto" } \\
\text { (KLEIMAN, 2009, p. 26). }\end{array}$ & $\begin{array}{lr}\text { "Geralmente } & \text { adquirido } \\
\text { informalmente, } & \text { através } \\
\text { de nossas experiências e } \\
\text { convívio } & \text { numa } \\
\text { sociedade" } & \text { (KLEIMAN, } \\
2009, \text { p. 22). } & \end{array}$ \\
\hline
\end{tabular}

De acordo com Kleiman (2009), todos devemos ter pelo menos uma noção sobre o que estamos lendo. Sem esse conhecimento prévio, a interpretação do que se está lendo poderá passar por barreiras e grandes dificuldades, podendo, inclusive, ser interrompida. Para que possam entender melhor sobre o que fala, Kleiman (2009, p. 14) fornece o seguinte exemplo:

(a) Consideremos, por exemplo, the analysis of myths. Antes de mais nada, é preciso proceder à syntagmatic decomposition of the pure mythical narration, isolando the constitutive units of the sequence.

Se o leitor se deparar com o texto acima sem ter conhecimento devido da língua inglesa, ele não terá meios nem mesmo para decodificar a mensagem. 
Ainda é possível observar outra situação envolvendo a informação dada no fragmento acima, agora considerando apenas a língua portuguesa, conforme sugere Kleiman (2009, p. 14):

(b) Consideremos, por exemplo, a análise dos mitos. Antes de mais nada, é preciso proceder à decomposição sintagmática da pura narração mítica, isolando as unidades constitutiva da sequência.

Nesse caso, o leitor, conhecedor do código apresentado, terá condições de decodificar o conteúdo do enunciado. Mas, ainda assim, se ele não possuir conhecimento sobre as palavras destacadas, por exemplo, a interpretação continuará comprometida, porque ele não conseguirá perceber as relações entre as palavras e muito menos realizar inferências.

É, de todas as maneiras, para o processo de interpretação bem sucedido, que a leitura seja guiada por objetivo(s). Segundo a mesma autora, isso "pressupõe reflexão e controle consciente sobre o próprio conhecimento, sobre o próprio fazer, sobre a própria capacidade. Opõe-se dessa maneira aos automatismos e mecanicismos típicos do passar o olho que muitas vezes é tido como leitura nas escolas" (KLEIMAN, 2009, p. 44-45). Ou seja, o leitor que vai ao texto com objetivos torna-se hábil não só para formular hipóteses a respeito do que lê, como também (inter)agir não como um mero receptor de informações.

Além desses dois mecanismos, os leitores devem ainda estar atentos a todas as marcas formais dos textos. Mediante isso, a captura dos implícitos que se encontram latentes no texto e aos quais precisará recorrer para sua boa interpretação fará dele um leitor perspicaz, habilidoso e mais seguro sobre a sua capacidade interpretativa. De acordo com Kleiman (2009), "o processo através do qual utilizamos elementos formais do texto para fazer as ligações necessárias à construção de um contexto é um processo inferencial de natureza inconsciente, sendo, então, considerada uma estratégia cognitiva” (KLEIMAN, 2009, p. 50. Grifo da autora).

Por fim, é importante interagirmos com a leitura. Esse caráter interacional é o que nos dará, no momento de uma interpretação, a possibilidade de reconhecermos as intenções do autor por meio de pistas linguísticas. Para Fávero (2009, p. 77), “é preciso que o leitor desenvolva habilidades que lhe permitam detectar as marcas que levarão às intenções do texto". Ora, a essa altura, claro está que o ato de interpretar não é uma atividade simples. Trata-se, antes, de um processo complexo, 
diante do qual todo leitor se verá enfrentando os desafios colocados pelo texto. Para ser bem sucedido, caberá ao leitor saber lançar mão de estratégias e técnicas de leitura mais elaboradas e eficientes.

O trabalho aqui realizado se volta, mais exatamente, para um estudo relacionado às marcas formais do texto, sejam eles verbais ou não verbais, como componente eficaz no processo interpretativo. Assim, se o leitor souber explorar o potencial que as imagens e as palavras adquirem no contexto em que aparecem, o trabalho de interpretação, de acordo com Porfírio e Bidarra (2008), começará fazer todo o sentido: é nesse instante que as intenções do produtor são captadas. Na charge, para retomarmos o objeto das nossas análises, cada detalhe encontrado nas figuras vem carregado de significado, e deverá ser considerado pelo leitor. Segundo Pereira (2003), quando o leitor consegue unir as informações passadas tanto pelo pictórico quanto pela palavra que vêm em sua sustentação, nesse momento, é porque o seu processamento mental atingiu o nível requerido para que a compreensão e interpretação da charge aconteçam.

\section{O GÊNERO CHARGE: INTERAÇÃO, INTERDICIPLINARIDADE E DINAMINICIDADE NO ENSINO-APRENDIZAGEM}

No mundo globalizado em que vivemos, encontramos uma ampla gama de recursos que podem ser colocados à disposição dos leitores com a finalidade de despertar a atenção e a curiosidade não apenas dos adultos, mas principalmente das crianças e adolescentes estudantes. Buscando explorar esse interesse, faz-se necessário que as práticas pedagógicas em sala de aula devam ser inovadoras e prazerosas (lúdicas). E é justamente nesse contexto que as charges se apresentam como um gênero textual cujas contribuições podem ser muito bem aproveitadas pelos professores e alunos, notadamente no que diz respeito ao trabalho interpretativo de textos.

O mundo moderno se caracteriza por "uma utilização da visualidade em quantidades inigualáveis na história, criando um universo de exposição múltipla para os seres humanos, o que gera a necessidade de uma educação para saber perceber e distinguir [...]", (BRASIL, 1998, p. 61). A "representação pictórica, de caráter burlesco e caricatural, em que se satiriza um fato específico, em geral de caráter político e que é do conhecimento da sociedade" (FERREIRA, 2004. p. 451). É nesse 
contexto que as charges se tornam um instrumento importante, porque em sua elaboração reúnem elementos importantes para despertar no aluno o gosto pela leitura. Segundo Bakhtin (2003), a charge é um gênero discursivo da esfera jornalística, organizado por elementos verbais e não verbais. Tem por função primeira provocar o humor e o riso, recursos para atrair o leitor para algo mais sério, revelado pela crítica que o chargista pretende veicular.

Apesar dos seus muitos recursos, à primeira vista apenas chamativos e interessantes, não podemos nos esquecer de que qualquer tentativa de interpretar uma charge vai exigir do leitor o estabelecimento de uma relaçao estrita entre a imagem, o escrito (se houver) e, é claro, o acontecimento atual. Dito de outro modo, se não for por outros motivos, as charges já se mostram relevantes na medida em que durante a sua elaboração tendem a ser entrelaçados os movimentos históricos, culturais, sociais e políticos de um povo (Cf. ASSIS, 2002).

Mas, com tantas possibilidades e formas distintas de exploração pedagógica e educacional, curioso é notar que muitas escolas e professores ainda encontram dificuldades em inserir as charges como uma atividade de leitura que dê um passo além da disciplinaridade. Sabemos que hoje o ensino formador de mentes críticas e atuantes necessita passar pela interdicplinaridade. De acordo com Fazenda (1991, p. 48), "a introdução da interdisciplinaridade implica simultaneamente numa transformação profunda da Pedagogia, num novo tipo de formação de professores e num novo jeito de ensinar (...)". Por meio dela, passa-se de uma relação pedagógica baseada na transmissão do saber de uma disciplina ou matéria, que se estabelece segundo um modelo hierarquico linear, para uma relação pedagógica dialógica na qual a posição de um é a posição de todos. Nesses termos, o próprio professor é beneficiado porque passa a ser mais atuante, crítico e animador por excelência (Cf. FAZENDA, 1991).

Para Paulo Freire (1987), a interdisciplinaridade é o processo metodológico de construçãoo do conhecimento pelo sujeito com base em sua relação com o contexto, com a realidade, com sua cultura. Assim sendo, a interdisciplinaridade, como um fenomeno metodológico, está impulsionando transformações no pensar e no agir humano em diferentes sentidos. Retoma, aos poucos, o caráter de interdependência e interatividade existentes entre as coisas e as ideias, resgata a visão de contexto da realidade, demonstra que vivemos numa grande rede ou teia de interações 
complexas, recupera a tese de que todos os conceitos e teorias estão conectados entre si. Nesta perspectiva, concordamos com Pessoa (2011), quando apregoa:

O uso da charge em atividades interdisciplinares propicia ao docente possibilidades pedagógicas em diversas áreas do conhecimento. No texto verbal e não verbal, o docente pode orientar projetos em redação, análise de discurso, elementos gramaticais do texto, coesão, coerência, aprendizagem de novas expressões, palavras e relação de temas pertinentes à comunidade da escola, com ênfase aos temas transversais. (PESSOA, 2011, p. 26).

O ensino se torna, cada vez mais, interdisciplinar e o professor além de utilizar as charges segundo os PCNs de sua área de atuação, deve considerar os PCNs de temas transversais. A própria construção das charges se faz por meio interdisciplinar, uma vez que são necessários conceitos de artes, literatura, história, física, geografia, sociologia e filosofia. A natureza interdisciplinar deste gênero permite, pois, uma gama de possibilidades educacionais que os professores devem considerar no ensino de linguagens em suas respectivas disciplinas (PESSOA, 2011).

Na construção do gênero charge, de imediato, já destacamos alguns fatores da textualidade fundamentais: a intertextualidade, a situacionalidade e a informatividade. Não tem como falar em análise de charges sem que nos remetamos à tríade, uma vez que o entendimento de tal texto está pautado em um conhecimento de mundo e às matérias do dia ou semana em que o texto foi vinculado. "O fato de encontrarmos, em textos vinculados pelo próprio jornal, informações diversas que nos permitam interpretar a charge, mostra que esta mantém relações intertextuais com os outros textos jornalísticos", (ROMUALDO, 2000, p. 26).

Somos partidários da ideia de que ao se trabalhar com charges, os alunos se sentirão mais motivados e curiosos, pois terão que buscar os conhecimentos em outros textos e terão de saber os fatos históricos nelas contidos. Pois, somente assim conseguirão alcançar a mensagem que foi passada. Por provocar muitas vezes o riso, o aprendizado se torna mais significativo e ao mesmo tempo prazeroso, sem que se perca de vista a preparação de sujeitos críticos na sociedade.

Tendo em vista que geralmente a charge é composta por assuntos que fazem parte da vida dos alunos, há, sem dúvida, a necessidade de reflexão mais profunda 
e crítica, que leve o aluno à inquietude, despertando-lhe o interesse pela pesquisa e investigação. Pois

é importante destacar que a charge, além do seu caráter humorístico, e, embora pareça ser um texto ingênuo e despretensioso, constitui uma ferramenta de conscientização, pois ao mesmo tempo em que diverte, informa, denuncia e critica, constitui-se um recurso discursivo e ideológico. (MOUCO, 2007, p. 31).

Nessa perspectiva, podemos perceber que a charge não se limita apenas a causar riso, mas objetiva criticar e discutir uma dada situação da atualidade. Para tanto, o leitor deverá estar sempre atualizado em relação aos acontecimentos sociais, pois assim, perceberá o que está implícito na informação deixada pelo autor. Nesse sentido, Romualdo (2000) diz que:

\begin{abstract}
Se pensarmos em termos de conteúdo, uma charge ou uma caricatura podem ser muito mais densas do que os outros textos opinativos, como uma crônica ou até mesmo um editorial. O leitor pode, inclusive, deixar de ler estes e outros gêneros opinativos convencionais, optando pela leitura da charge que, por ser um texto imagético e humorístico, atrai mais sua atenção e lhe transmite mais rapidamente um posicionamento crítico sobre personagens e fatos políticos. (ROMUALDO, 2000, p. 15).
\end{abstract}

A charge, por todas as questões citadas, é uma forma dinâmica e interativa de investir no ensino aprendizagem, que deve ser repensada na prática docente, para que a considere como mais um dos recursos positivos, necessários e plausíveis no ensino.

\title{
6 ANÁLISE DA CHARGE "ELEIÇÃO PARA PAPA"
}

Com base nas discussões feitas aqui, selecionamos para as nosssas análises e reflexões a Charge intitulada "Eleição para Papa" de Alberto Benett (2013). A escolha se deu em função da riqueza não apenas imagética, mas textual que a charge traz em sua construção. Desse modo, pudemos considerar no processo de interpretação todas as manifestações verbais e não verbais presentes no texto. Senão, vejamos: 
Figura 01 - "Eleição para Papa"

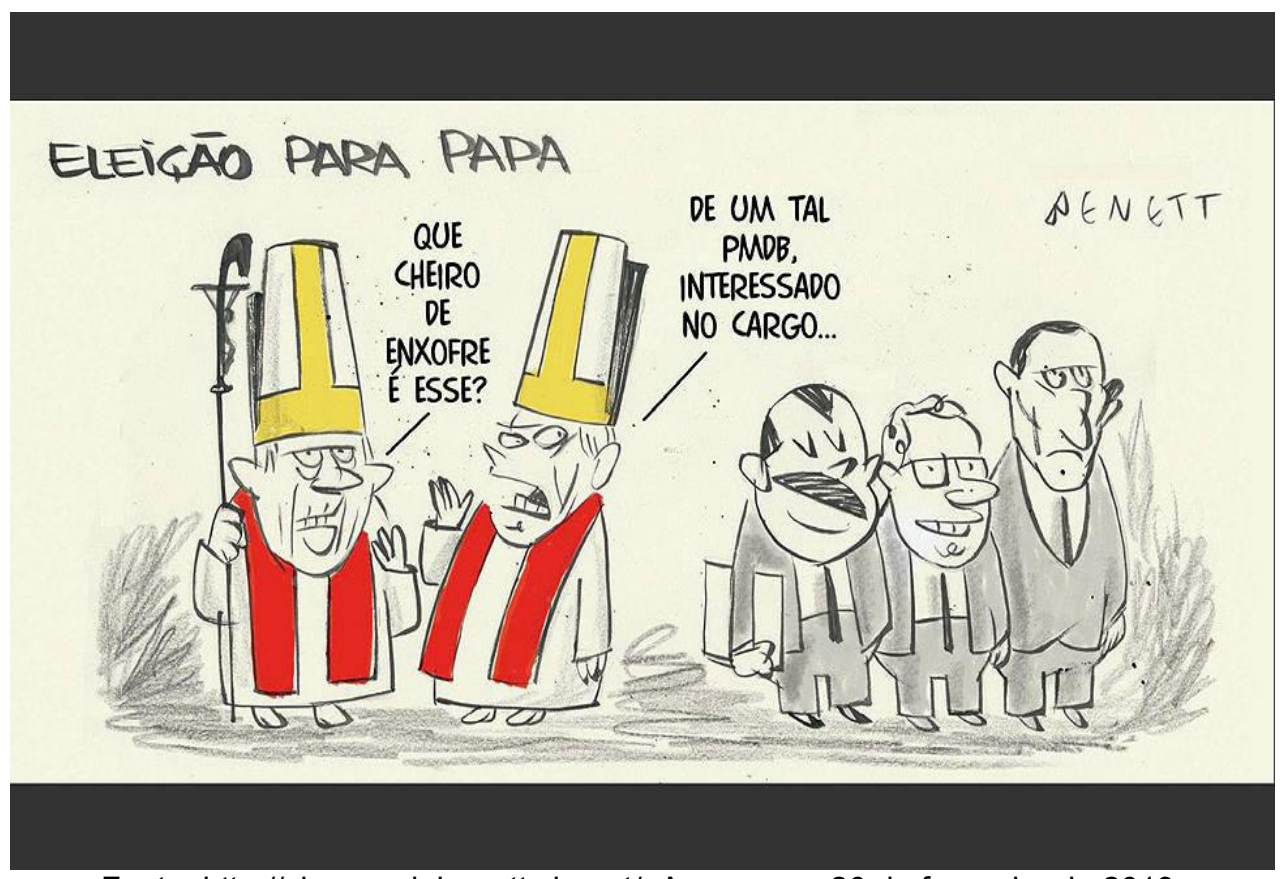

Fonte: http://chargesdobenett.zip.net/. Acesso em 20 de fevereiro de 2013.

O aluno, para compreender a charge, deve ter conhecimento prévio acerca de assuntos atuais relacionados à religião e à política, principalmente. Ou seja, dentre outras coisas, ele precisa ter algum conhecimento sobre a renúncia do papa Bento VXI, recentemente ocorrida. Por isso, cabe-nos nesse momento abrir um espaço para relembrarmos o episódio, conforme reportagem da revista $V_{E J A}{ }^{3}$, na manhã do dia 11 de fevereiro de 2013, o papa surpreendeu o mundo com a notícia de que deixaria o pontificado ao fim daquele mês. Em latim, durante um consistório para a canonização de dois mártires no Vaticano, o pontífice, de 85 anos, afirmou que estava renunciando devido à idade avançada, por "não ter mais forças" para exercer o cargo. O último papa a renunciar antes de Bento XVI foi Gregório XII, em 1415. Esse fato permite inferir que logo haverá a eleição de outro papa.

Além desse conhecimento, o aluno também terá de saber que, no campo da política, o PMDB, neste ano de 2013, está no comando da Câmara e do Senado, tendo em vista que o deputado federal Henrique Eduardo Alves (PMDB-RN) foi eleito presidente da Câmara e o Senador Renan Calheiros (PMDB-AL), presidente do Senado. Mais do que isso, o aluno também deve ter ciência sobre a função que esses dois personagens passarão a ter no exato momento em que assumirem os cargos para os quais foram eleitos. 
No bojo do conhecimento exigido, é ainda fundamental que o aluno tenha algum conhecimento prévio sobre a vida política destes presidentes (Câmara e Senado). Nesta perspectiva, não há como desconsiderar que, nas últimas semanas, Henrique Eduardo Alves foi alvo de denúncias ${ }^{4}$ de que teria beneficiado a empresa de ex-assessor com emendas parlamentares destinadas a obras no Rio Grande do Norte.

No mês passado, Aloizio Dutra de Almeida, que trabalhava há 13 anos no gabinete de Alves, pediu demissão. Além disso, uma reportagem da revista VEJA ${ }^{5}$ revelou que o deputado destinou verbas de gabinete para contratar serviços de uma locadora de carros de fachada, em nome de um laranja.

Quanto ao presidente do Senado, o arsenal de denúncias contra Renan Calheiros, que motivou seu afastamento do cargo de presidente do Senado em 2007, foi revitalizado com a proximidade das eleições para a presidência da Casa. Em 2007, VEJA revelou que o senador se valia do lobista Cláudio Gontijo, da empreiteira Mendes Júnior, para pagar a pensão alimentícia da filha que teve com a jornalista Mônica Veloso. Em sua defesa, Renan argumentou que tinha obtido lucro espantoso com a venda de gado. As investigações, entretanto, concluíram que as notas fiscais apresentadas eram falsas. O procurador-geral da República, Roberto Gurgel, confirmou que apresentou denúncia contra Renan ao Supremo Tribunal Federal (STF) pelos crimes de falsidade ideológica, peculato e uso de documentos falsos.

Todos esses fatos reunidos podem ser trazidos à tona porque fartamente veiculado pela imprensa nacional e até internacional. Estes conhecimentos (de mundo, textual e linguístico) são fundamentais para que o aluno consiga interagir com a charge em questão, iniciando, assim, a construção do significado da mesma. Neste sentido, segundo Kleiman (2009, p. 25), "este tipo de inferência, que se dá como decorrência do conhecimento de mundo e que é motivado pelos itens lexicais no texto é um processo inconsciente do leitor proficiente".

Nesse exercício interpretativo, também devemos levar em consideração todas as marcas formais do texto, como já mencionamos antes. Conforme Kleiman (2009), os sentidos serão mais bem captados se soubermos ler os implícitos, uma vez que eles podem ser recuperados tanto pela linguagem verbal, quanto pela não verbal. Em outras palavras, para ter uma interpretação textual bem sucedida, é necessário considerar que a imagem dessa charge vem carregada de significados, uma vez 
que, no primeiro plano do texto, está a caricatura de dois Cardeais que conversam sobre os três componentes ao lado, representantes do partido político PMDB. Cabe lembrar que, nos meios religiosos, o enxofre tem um significado muito forte, referindo-se a uma entidade maligna e, portanto, indesejável.

O código não verbal "Que cheiro de enxofre é esse?" usado por um dos cardeais representa a presença do grupo PMDB que está atualmente na presidência de cargos relevantes na política brasileira, e que são alvos de denúncias. Significa que quando a coligação PMDB está reunida, o cheiro de enxofre se volatiza pelos ares, contagiando tudo que está por perto. Além disso, podemos inferir que tal grupo político está concorrendo a cargos do mais alto nível, o que permitiu investir até a candidatura de Papa. Caso eleito nesta ultima instância, proporcionará o comando político e também religioso. Claro que, à primeira vista, essa mistura política civil com a política religiosa adotada para a candidatura ao cargo de Papa visa provocar o humor, o riso. Contudo, muito além disso, o objetivo do chargista é bem outro: pelo riso, atrair o leitor para uma crítica política que é séria, mas feita de forma descontraída e mais leve que outros gêneros dentro da mesma esfera ou suporte.

\section{CONSIDERAÇÕES FINAIS}

Ao longo desse artigo, vimos que o processo de construção de significado textual do gênero charge é realizado por sujeitos, num processo de interação, o que significa dizer que carrega, dentre outros aspectos, os interesses e os pontos de vista dos interlocutores envolvidos no discurso.

Considerando, pois, o texto como uma atividade interativa por meio do qual se atualiza o discurso, na forma de um dado gênero, de imediato, verificamos que interpretar um texto não é algo simples. Ao contrário, é uma tarefa árdua que exige atenção do leitor, pois "é no interior do ato de leitura, enfrentando os desafios colocados pelo texto, que se aprende a usar as estratégias de leitura como ferramenta para desenvolver técnicas próprias e eficientes para o processo interpretativo" (KLEIMAN, 2009, p. 56).

Constatamos ainda que para a interpretação da charge foi fundamental estabelecer intertextualidade com outros textos jornalísticos que trataram dos fatos políticos aqui mencionados. Foi todo esse movimento que possibilitou compreender o significado das manifestações verbais e não verbais. Não seria possível ir além da 
superfície textual se não fossem acionados os conhecimentos prévios referentes ao assunto elencado na charge. Dentre tais conhecimentos, o de mundo, como se percebe, foi imprescindível para construção de inferências e, consequentemente, de significado textual.

Assim, pudemos verificar que a charge, mais do que uma simples piada, é um gênero rico para se trabalhar numa perspectiva interdisciplinar, pois para sua compreensão acionou-se conhecimentos de diversas áreas, dentre eles, política, religião, história, geografia, língua portuguesa, artes, sociologia, filosofia, etc. Considerando o caráter informativo e opinativo das charges, bem como a ampla circulação social das mesmas, acreditamos que o trabalho interdisciplinar com o gênero contribuirá para a formação de cidadãos pensantes e críticos perante a sociedade.

\title{
NOTAS
}

1 Atualmente em pós-doutorado na área do Processamento da Linguagem Natural e Linguística Computacional. Doutor em Linguística (Computacional) pelo Instituto de Estudos da Linguagem (IEL)/UNICAMP. Professor Associado B da Graduação e da Pós-graduação da Universidade Estadual do Oeste do Paraná - UNIOESTE.

2 Mestra em Letras pela UNIOESTE. Professora da Graduação e da Pós-graduação da Associação Juinense de Ensino Superior do Vale do Juruena - AJES. Coordenadora do PIBID/Letras da AJES.

3 Disponível em http://veja.abril.com.br/tema/renuncia-do-papa-bento-xvi, em 21 de Fevereiro de 2013.

4 Disponível em http://radioglobo.globoradio.globo.com/noticias/2013/02/04/ALVO-DE-DENUNCIASDEPUTADO-HENRIQUE-EDUARDO-ALVES-E-ELEITO-PRESIDENTE-DA-CAMARA, em 21 de Fevereiro/2013.

5 Disponível em http://veja.abril.com.br/blog/reinaldo/geral/56-a-18-e-renan-denunciado-por-trescrimes-volta-a-presidencia-do-senado-ou-quem-prometeu-voto-a-taques-e-nao-entregou-em-troca-deque/, em 21 de Fevereiro/2013.

\section{CHARGE GENDER: CONSTRUCTION OF MEANING FROM AN INTERDISCIPLINARY PERSPECTIVE AND DYNAMIC}

\begin{abstract}
This paper discusses and analyzes the interpretative process of the genre charge, taking into account its role in teaching and learning. Therefore, the discussion is based on the approach sociointeractionist of the language, to which the text should be seen as an interactional, creative and social activity. Starting from this point of view, interpreting a text becomes a complex task that requires cognitive and
\end{abstract}


metacognitive strategies. For our debate, we select the Charge entitled "Election to Pope," written by Alberto Bennett (2013). Throughout the text, we show that in the case of cartoons, one of the key requirements is the establishment of intertextuality, especially with the involvement of other journalistic texts. We also observed that, in such circumstances, without proper activation of prior knowledge (knowledge of the world and language, for example), the interpretation made by the reader tends to fail. Because it is a genre composed by mixing verbal with nonverbal (pictorial), we defend that the charge must be regarded as a very rich material to be worked with students in classrooms. The interpretation of the cartoons requires, often involving knowledge not only politics and religion, but also the facts of history, geography, art and of the language. The character humorous, informative and opinionated of the cartoons, as well as the broad social movement to assume the charge make an important instrument for the formation of critical and reflective students, attributes increasingly requested by society.

Keywords: Textual interpretation. Text. Gender charge. Interdisciplinarity. Teaching and Learning.

\section{REFÊRENCIAS}

BAKHTIN, Mikhail. A estética da criação verbal. Trad. Paulo Bezerra. 4. ed. São Paulo: Martins Fontes, 2003.

. Marxismo e filosofia da linguagem.Trad. Michel Lahud e Yara Frateschi Vieira. 9. ed. São Paulo: Huciec, 2002.

BRASIL. Secretaria de Educação Fundamental. Parâmetros curriculares nacionais: terceiro e quarto ciclos de ensino fundamental: língua portuguesa. Brasília: MEC/SEF, 1998.

COSTA VAL, Maria da Graça. Redação e textualidade. 2. ed. São Paulo: Martins Fontes, 1999.

FAZENDA, Ivani. Integração e interdisciplinaridade no ensino brasileiro. São Paulo: Loyola, 1993.

FÁVERO, Leonor Lopes. Coesão e coerência textuais. 11. ed. São Paulo: Ática, 2009.

FERREIRA, Aurélio B. de H. Novo dicionário Aurélio da língua portuguesa. 3 ed. Curitiba: Positivo, 2004.

FREIRE, Paulo. Pedagogia do oprimido. Rio de Janeiro: Paz e Terra, 1987.

KLEIMAN, Ângela Bustus. Texto e leitor: aspectos cognitivos da leitura. São Paulo: Pontes, 2009.

. Oficina de leitura: teoria e prática. 10. ed. Campinas: Pontes, 2004. 
$\mathrm{KOCH}$, Ingedore Grunfeld Villaça. O texto e a construção dos sentidos. São Paulo: Contexto, 2008.

A inter-ação pela linguagem. 6. ed. São Paulo: Contexto, 2001.

$\mathrm{KOCH}$, Ingedore G. V.; ELIAS, Vanda Maria. Ler e compreender: os sentidos do texto. São Paulo: Contexto, 2006.

KOCH, Ingedore G. V; MARCUSCHI, Luiz Antônio. Processo de referenciação na produção discursiva. DELTA - Revista de Documentação de Estudos em Linguística Teórica e Aplicada, São Paulo, v. 14, n. especial, p. 169-190, 1998.

MACHADO, Elisabeth Márcia Ribeiro. Lendo e compreendendo: uma experiência com $5^{a}$ série. 2002. Dissertação (Mestrado em Linguística) - Instituto de Estudos da Linguagem, Universidade Estadual de Campinas, Campinas, 2002.

MARTINS, Maria Helena. O que é leitura? 19. ed. São Paulo: Brasiliense, 2006. (Coleção Primeiros Passos).

MENEGASSI, Renilson José. Compreensão e interpretação no processo de leitura: noções básicas ao professor. UNIMAR, Maringá, v. 17(I), p. 85-94, 1995.

MOUCO, Maria Aparecida Tavares. Leitura, análise e interpretação de charges com fundamentos na teoria semiótica. São Paulo: Martins Fontes, 2007.

PESSOA, Valda Inês Fontenele. O cuidado interdisciplinar na construção de um currículo de formação de educadores. São Paulo: PUCSP, 2011.

PORFÍRIO, Lucielen; BIDARRA, Jorge. A extração de informação aplicada à interpretação de textos: um estudo de caso sobre textos no domínio da gastroenterologia. Veredas - Revista de Estudos Linguísticos, Juiz de Fora, n. 1, p. 80-94, 2008.

ROJO, Roxane. Letramento e capacidades de leitura para a cidadania. Texto inédito. LAEL/PUC-SP (SEE-SP, SME-SP/CENPEC), 2002.

ROMUALDO, Edson Carlos. Charge jornalística: intertextualidade e polifonia: um estudo de charges da Folha de S. Paulo. Maringá: Eduem, 2000.

TRAVAGLIA, Luiz Carlos. Gramática e interação: uma proposta para o ensino de gramática no $1^{\circ}$ e $2^{\circ}$ graus. 5. ed. São Paulo: Cortez, 2000. 